\title{
FDI-Led-Growth in Malaysia: Autoregressive Distributed Lag (ARDL) Bounds Testing Approach
}

\author{
Jerome Kueh ${ }^{1}$, Yong Sze Wei ${ }^{2}$ \\ ${ }^{1}$ Faculty of Economics and Business, Universiti Malaysia Sarawak, 94300 Kota Samarahan, Sarawak, Malaysia \\ ${ }^{2}$ Faculty of Business and Management, Universiti Teknologi MARA, 94300 Kota Samarahan, Sarawak, \\ Malaysia \\ Correspondence: Jerome Kueh, Faculty of Economics and Business, Universiti Malaysia Sarawak, 94300 Kota \\ Samarahan, Sarawak, Malaysia.
}

Received: September 14, 2018

Accepted: October 9, 2018

Online Published: October 11, 2018

doi:10.5539/ibr.v11n11p46

URL: https://doi.org/10.5539/ibr.v11n11p46

\begin{abstract}
This study intends to investigate the validity of the foreign direct investment, FDI-led-growth hypothesis in Malaysia in this era. Autoregressive Distributed Lag (ARDL) bounds test approach is adopted to examine the impact of FDI inflow towards growth of Malaysia based on annually data from 1980 to 2016. Empirical results indicate that FDI inflow has significant positive impact on economic growth. This implies that FDI inflow remain important tool for stimulating economic growth of Malaysia. In addition, there is a negative impact of FDI inflow on economic growth during the 1997 Asian Financial crisis and positive impact during the 2008 Global Financial crisis. In terms of policy recommendation, the policy makers should continue to develop strategies to further attract FDI that will contribute to increasing the productivity in the country.
\end{abstract}

Keywords: foreign direct investment, ARDL bound test, economic growth

\section{Introduction}

Foreign direct investment (FDI) has been the engine of growth in Association of Southeast Asian Nations (ASEAN) in the 1990s. This can be seen from the influx of FDI into ASEAN-5 countries, namely Indonesia, Malaysia, Philippines, Singapore and Thailand. The spillover effects of FDI can be in the form of human capital development, new technology and management skill transfer, stimulate the international trade activity and ultimately contribute to the economic growth of the countries (Blomstrom and Wolff, 1994; Chuang and Hsu, 2004; Dollar and Kraay, 2004; Hermes and Lensink, 2003; Schneider, 2005; Li and Liu, 2005; Wang and Yu, 2007).

Table 1. Selected Macroeconomics Indicators of Malaysia

\begin{tabular}{lccccccc}
\hline & $\mathbf{1 9 8 9 - 1 9 9 2}$ & $\mathbf{1 9 9 3 - 1 9 9 6}$ & $\mathbf{1 9 9 7 - 2 0 0 0}$ & $\mathbf{2 0 0 1 - 2 0 0 4}$ & $\mathbf{2 0 0 5 - 2 0 0 8}$ & $\mathbf{2 0 0 9 - 2 0 1 2}$ & $\mathbf{2 0 1 3 - 2 0 1 6}$ \\
\hline GDP $(\%)$ & & & & & & & \\
FDI & 9.13 & 9.73 & 3.69 & 4.62 & 5.42 & 4.20 & 4.99 \\
& $3,364.97$ & $5,858.50$ & $4,179.97$ & $2,713.68$ & $6,473.01$ & $7,987.36$ & $11,010.06$ \\
Total Trade (\%) & 148.38 & 177.93 & 208.28 & 201.82 & 193.89 & 155.82 & 135.81 \\
& & & & & & & \\
Domestic Credit & & & & & & & \\
$(\%)$ & 99.65 & 123.46 & 153.49 & 139.38 & 113.13 & 127.15 & 142.21 \\
\hline
\end{tabular}

Source: World Economic Outlook, UNCTACD and World Development Indicator.

Table 1 indicates selected macroeconomics indicators of Malaysia based on 4 years average from 1992 to 2016. Malaysia has experienced tremendous economic growth prior 1997 with average GDP growth at $9.13 \%$ and $9.73 \%$ in the period of 1989-1992 and 1993-1996, respectively. In terms of FDI inflow, Malaysia recorded US\$3,365 million in the period of 1989-2002 and increased to US\$5,859 in the period of 1993-1996. This increasing 
pattern did not persist and decrease to US\$4,180 and US\$2,714 in the period of 1997-2000 and 2001-2004, respectively. The remarkable FDI inflows into Malaysia in the early 1990s indirectly contributed to the economic growth as Malaysia has become one of the favourite FDI destination. However, the 1997 Asian Financial crisis has caused severe negative impact on the FDI inflow and eventually affecting the economic growth. Since then, the GDP growth and FDI inflow into Malaysia gradually improving. Interestingly, the 2008 Global Financial crisis have minimal impact on Malaysia. This can be seen from the slight decrease of GDP growth from 5.42\% in the period of 2005-2008 to 4.20\% in the period of 2009-2012. Meanwhile, FDI inflow shown a slow increase from US\$6,473 to US\$7,987 in the subsequent period of 2005-2008 and 2009-2012, respectively. In terms of GDP performance, the country recorded the highest GDP growth at average 9.73\% in the period 1993-1996 before drastic decline to average $3.60 \%$ in the period 1997-2000. The subsequent period of years indicated stable GDP growth at around 4\%, with average $4.99 \%$ in the period 2013 to 2016. Meanwhile, Malaysia recorded highest level of total trade with average 208\% of GDP in the period 1997 to 2000. However, it declined to average $135 \%$ in the period of 2013 to 2016. Domestic credit also portrayed the highest level of average $153 \%$ of GDP in the period of 1997 to 2000. Although there was a slight declination of the domestic credit level in the subsequent periods, it recorded at average 142\% of GDP in the period of 2013 to 2016.

The relationship between FDI and economic growth has received much attention among the researchers. This is due to the positive spillover effects of FDI towards economic growth of the host country (see for example: Chakraborty and Basu, 2002; Liu, Burridge and Sinclair, 2002; Chowdhury and Mavrotas, 2005; Li and Liu, 2005; Duasa, 2007; Carbonell and Werner, 2018). Nevertheless, the contribution of the FDI to economic growth has comes to the point of concern, particularly the effects of crisis such as financial crisis. This is due to the severe negative impact on the FDI inflow during the crisis periods such as 1997 Asian Financial crisis and 2008 Global Financial crisis. For instance, ASEAN region, especially Malaysia has become the main attraction of FDI preference in the 1990s as shown in Table 1. However, the consequences of the 1997 Asian financial crisis led to the drastic declination of the FDI inflow from US\$7,297 million in 1996 to US\$2,714 million in 1998. Similarly, during the 2008 Global Financial crisis, FDI inflow into Malaysia recorded severe drop from US\$8,585 in 2007 to US\$1,453 in 2009. Furthermore, the intense rivalry among the ASEAN tigers (Indonesia, Malaysia, Thailand and Philippines), emerging economies such Vietnam and the rise of China have become a challenge among the nations in attracting FDI inflow.

This phenomenon indirectly indicates although FDI plays significant role in stimulating economic growth of a country, however, uncertainties such as financial crisis and challenges among the nations to become FDI preference destination has lay a doubt on the role of FDI towards economic growth in this era. In other perspective, it is undeniable the fact that FDI spillover effects contributed to the economic growth, but the relevancy of the FDI role in ensuring sustainable economic growth cast further doubt among the policy makers. This is due to the nature of the FDI, which can be in the form of greenfield investment and equity. The greenfield investment FDI in general will take a longer time period to observe the impact as it is considered long-term investment. Equity investment FDI is viewed as short term investment and may subject to fluctuation of the business. Both FDI forms have their respective risk level and eventually may dampen economic growth due to unforeseen circumstances.

Therefore, it is important to re-examine the role of FDI towards economic growth of Malaysia, especially to ensure sustainability growth of the country in view of the nature of the FDI and challenges in attracting the FDI inflow into Malaysia due to the competitive advantage in terms of labor cost in other countries such as China and Vietnam. The contributions of this study are two folds. Firstly, the findings from this study are essential to the policy makers as to ensure the relevancy of the FDI in stimulating growth in the recent business and economics environment. With regards to that, the government may develop relevant strategies to ensure sustainable FDI inflow into the country if FDI is still valid in contributing to economic growth. Secondly, the revisit of the role of FDI towards economic growth by incorporating the effect of financial crises further provide new insight on the association between FDI and economic growth.

The remainder of this paper is structured as follows: Section 2 provides discussion on the literature about FDI led growth, section 3 shows the methodology adopted, section 4 provides discussion of the results obtained. Finally, section 5 provides concluding remarks.

\section{Literature Review}

There are several empirical literatures shown the evidence of FDI-led growth where FDI plays essential role in contributing to economic growth of a country.

Borensztein et al. (1998) conducted study on 69 developing countries from 1970 to 1989 with the aim to 
examine the relationship between FDI and economic growth. Their findings indicated that FDI is an important tool contributing to economic growth via transfer of technology. Zhang (2001) examined the validity of the FDI-led-growth hypothesis at a broader aspect where the sample countries are East Asian and Latin American countries. He discovered that there is a mixed result where some countries showed evidence of FDI-led growth and some countries exhibited the opposite direction causality. Chakraborty and Basu (2002) investigated the causality direction between FDI and economic growth of India from 1974 to 1996 using vector error correction model (VECM), The causality result indicated that GDP causal FDI instead of the other way for India case. Liu, Burridge and Sinclair (2002) performed empirical analysis FDI, trade and growth of China from 1981 to 1997. Their findings showed that there is bi-directional causality between FDI, trade and economic growth. In other words, FDI plays an important role in stimulating economic growth of China. Meanwhile, Chowdhury and Mavrotas (2005) investigated the causality between FDI and growth using Toda-Yamamoto method for three countries, namely Chile, Malaysia and Thailand from 1969 to 2000. Their results indicated that causality from growth to FDI for the case of Chile, but bi-directional causality between FDI and growth for the case of Malaysia and Thailand. Li and Liu (2005) examined the impact of FDI on growth on 84 countries from 1970 to 1999. They proclaimed that FDI has positive impact on economic growth, particularly via human capital element. On the other hand, Duasa (2007) investigated the causality between FDI and economic growth as well as FDI and stability of growth in Malaysia. Empirical results indicated no causality between FDI and growth, but FDI contribute to the growth stability of Malaysia.

Batten \& Xuan (2009) conducted a study on examining the relationship between FDI and economic growth for 79 countries that include developed and developing countries, from 1983 to 2003 using panel data. The findings indicated that FDI has positive impact on economic growth and tends to be stronger in the countries with higher level of education, trade openness, stock market development and lower rate of population growth. Schmitt and Alexiou (2016) examined the FDI-led-growth hypothesis for Ireland from 1976 to 2011 using VECM. Their empirical results showed that there is a significant positive association between FDI and economic growth in the long-run and short-run. Mahmoodi and Mahmoodi (2016) examined the causal relationship between FDI, exports and economic growth for two groups of countries that consists of eight European developing countries and eight Asian developing countries. The sample period for first group is from 1992 to 2013 while the for second group is from 1986 to 2013. They adopted panel VECM and causality method to investigate the tri-variate model. Their empirical results showed that evidence of bidirectional causality between FDI and economic growth and unidirectional causality from economic growth and FDI to exports in developing European countries and Asian countries.

\section{Methodology}

The sample period used in this study covers from 1980 to 2016. Gross domestic product is the dependent variable, whereas FDI inflow as the main independent variable. Total trade, domestic private credit and population are included in the model as control variables. All the variables are obtained from World Development Indicator (WDI). All the variables are transformed into logarithm form with the aim to standardize the different measurement units.

\begin{tabular}{lrr}
\hline \multicolumn{1}{c}{ Variables } & Measurement & Source \\
\hline Gross domestic product & Constant in local currency & \\
FDI inflow & Current US\$
\end{tabular}

Total trade Sum of exports and imports of goods and services measured as a share of World Development Indicator (WDI) gross domestic product

Domestic private credit

Percentage of GDP

Population

Total population in persons

In order to examine the impact of the FDI inflow and economic growth, the following models specification are developed:

Model A: $\quad$ Baseline model with control variables as shown in Equation (1)

Model B: $\quad$ Baseline model with control variables, 1997 crisis dummy and 2008 crisis dummy as shown in Equation (2)

Model C: $\quad$ Baseline model with control variables, interaction terms between FDI and 1997 crisis dummy, 
interaction terms between FDI and 2008 crisis dummy as shown in Equation (3)

$$
\begin{aligned}
& L G D P_{t}=\alpha+\beta_{1} L F D I+\beta_{2} L T T_{t}+\beta_{3} L D C_{t}+\beta_{4} L P O P_{t}+\varepsilon_{t} \\
& L G D P_{t}=\alpha+\beta_{1} L F D I+\beta_{2} L T T_{t}+\beta_{3} L D C_{t}+\beta_{4} L P O P_{t}+\beta_{5} D 1_{1997}+\beta_{6} D 2_{2008}+\varepsilon_{t} \\
& L G D P_{t}=\alpha+\beta_{1} L F D I+\beta_{2} L T T_{t}+\beta_{3} L D C_{t}+\beta_{4} L P O P_{t}+\beta_{5}\left(F D I * D 1_{1997}\right)+\beta_{6}\left(F D I * D 2_{2008}\right)+\varepsilon_{t}
\end{aligned}
$$

where $L G D P$ denotes logarithm of GDP, LFDI denotes logarithm of FDI inflow, LTT denotes logarithm of total trade, $L D C$ denotes logarithm of domestic private credit, $L P O P$ denotes logarithm of population, $D 1_{1997}$ denotes 1997 Asian financial crisis, $D 2_{2008}$ denotes 2008 Global financial crisis, $\left(F D I * D 1_{1997}\right)$ denotes interaction terms between FDI and 1997 Asian financial crisis, $\left(F D I * D 2_{2008}\right)$ interaction terms between FDI and 2008 Global financial crisis and $\varepsilon$ denotes white noise error term.

This study adopts Autoregressive Distributed Lag (ARDL) bounds testing approach proposed by Pesaran et al. (2001) to determine the long-run relationship among the variables. Narayan and Narayan (2005) stated that the bounds test is based on the estimation of unrestricted error correction model (UECM) and has several advantages compared to cointegration approach. First, the ARDL approach does not require the stationarity of $I(1)$ for all the variables as the $F$-statistics has non-standard distribution under the null hypothesis of no-cointegration, regardless the variables are $I(0)$ or $I(1)$. Second, it is applicable and robust for small sample. Third, it can estimate the short-run and long-run parameters simultaneously.

The UECM is expressed in Equation (4):

$$
\begin{gathered}
\Delta L G D P_{t}=\alpha+\sum_{i=1}^{p} \beta_{1} \Delta L G D P_{t-i}+\sum_{i=1}^{p} \beta_{2} \Delta L F D I_{t-i}+\sum_{i=1}^{p} \beta_{3} \Delta L T T_{t-i}+\sum_{i=1}^{p} \beta_{4} \Delta L D C_{t-i}+\sum_{i=1}^{p} \beta_{5} \Delta L P O P_{t-i} \\
+\lambda_{1} L G D P_{t-i}+\lambda_{2} L F D I_{t-i}+\lambda_{3} L T T_{t-i}+\lambda_{4} L D C_{t-i}+\lambda_{5} L P O P_{t-i}+\varepsilon_{t}
\end{gathered}
$$

where $\Delta$ denotes a first difference operator.

The long-run relationship is determined via $F$-statistic or Wald statistic based on the null hypothesis of no cointegration, $H_{0}: \lambda_{1}=\lambda_{2}=\lambda_{3}=\lambda_{4}=\lambda_{5}=0$ and alternative hypothesis, $H_{1}: \lambda_{1} \neq \lambda_{2} \neq \lambda_{3} \neq \lambda_{4} \neq \lambda_{5} \neq 0$. The null hypothesis can be rejected if the calculated $F$-statistics value is larger than the critical value of the upper bounds and this indicates there is long-run relationship between the variables. The null hypothesis cannot be rejected if the $F$-statistic value is less than the lower critical value and this indicates that there no long-run relationship between the variables. If the $F$-statistic value falls in between the lower and upper bounds, the test will be inconclusive. The optimal lag length can be selected based on Schwartz-Bayesian Criteria (SBC) and Akaike Information Criteria (AIC).

If there is long-run relationship among the variables, the error correction model is represented as stated:

$$
\begin{gathered}
\Delta L G D P_{t}=\alpha+\sum_{i=1}^{p} \beta_{1} \Delta L G D P_{t-i}+\sum_{i=1}^{p} \beta_{2} \Delta L F D I_{t-i}+\sum_{i=1}^{p} \beta_{3} \Delta L T T_{t-i}+\sum_{i=1}^{p} \beta_{4} \Delta L D C_{t-i}+\sum_{i=1}^{p} \beta_{5} \Delta L P O P_{t-i} \\
\quad+\partial E C T_{t-i}+\varepsilon_{t}
\end{gathered}
$$

where $E C T_{t-i}$ term denotes the long-run equilibrium speed of adjustment. Diagnostic tests such as normality 
test, serial correlation test and heteroscedasticity test will be performed to ensure the goodness of fit of the model while cumulative sum (CUSUM) and cumulative sum of square (CUSUMSQ) will be performed to check the stability of the model.

\section{Empirical Results}

Table 2 shows the Unit Root test results for Augmented Dickey Fuller (ADF), Philips Perron (PP) and Kwiatkowski-Phillips-Schmidt-Shin (KPSS). The objective of conducting the unit root test is to check the stationarity of the time-series variables as either integrated with the same order at level or at first difference.

Table 2. Unit Root Test Results

\begin{tabular}{lcccccc}
\hline & $\begin{array}{c}\text { Augmented Dickey-Fuller } \\
\text { (ADF) }\end{array}$ & \multicolumn{2}{c}{$\begin{array}{c}\text { Philips Perron } \\
\text { (PP) }\end{array}$} & \multicolumn{2}{c}{$\begin{array}{c}\text { Kwiatkowski-Phillips-Schmidt-Shin } \\
\text { (KPSS) }\end{array}$} \\
\hline Variables & At Level & $\begin{array}{c}\text { First } \\
\text { Difference }\end{array}$ & At Level & $\begin{array}{c}\text { First } \\
\text { Difference }\end{array}$ & At Level & First Difference \\
\hline LGDP & -1.2152 & $-4.8512 * * *$ & -1.3859 & $-4.8598^{* * *}$ & $0.1618^{* *}$ & 0.1739 \\
LFDI & $-4.9310^{* * *}$ & $-6.6373^{* * *}$ & $-4.9310^{* * *}$ & $-18.673^{* *}$ & $0.0697 * * *$ & 0.2585 \\
LTT & 0.3828 & $-3.4459^{* *}$ & 0.1129 & $-3.4926^{* *}$ & $0.1801 * * *$ & 0.4893 \\
LDC & -3.0992 & $-5.3758^{* * *}$ & -3.1781 & $-5.5851^{* * *}$ & 0.0992 & 0.1031 \\
LPOP & $-3.7551^{* *}$ & -0.5926 & 0.9724 & -0.0346 & $0.1931^{* *}$ & 0.5968 \\
\hline
\end{tabular}

Notes: Asterisks *, ** and $* * *$ denote significance levels: $10 \%, 5 \%$ and $1 \%$. LGDP = logarithm of GDP, LFDI = logarithm of FDI inflow, LTT = logarithm of total trade, LDC = logarithm of domestic private credit and LPOP $=$ logarithm of population. Automatic lag selection by Schwarz Info Criterion (SIC) for ADF. Null hypothesis under ADF test and PP test state that time series variable is non-stationary, while null hypothesis under KPSS test states that time series variables is stationary.

Under the ADF test, LGDP, LTT and LDC are non-stationary at level (non-rejection of null hypothesis of variable contain unit root) but become stationary at first difference, except for LFDI and LPOP where they are stationary at level. Under the PP test, LGDP, LTT, LDC and LPOP are non-stationary at level and become stationary at first difference except for LFDI where it is stationary at level. Under the KPSS test, LGDP, LTT, LDC and LPOP are non-stationary at level (rejection of null hypothesis of variable is stationary) and become stationary at first difference except for LDC where it is stationary at level. Therefore, there is a mix results on the stationarity of the time-series variables as either stationary at level or at first difference. Due to that, ARDL bounds test can be adopted since there are some variables exhibit stationarity at level or at first difference and it is not a precondition for performing ARDL bounds test.

Table 3. ARDL Bound Test Results

\begin{tabular}{|c|c|c|c|c|c|c|}
\hline \multirow{2}{*}{$\begin{array}{l}\text { Bounds test } \\
F \text {-statistics }\end{array}$} & \multicolumn{2}{|c|}{$\begin{array}{c}\text { Model A: } \\
(1,0,4,1,4)\end{array}$} & \multicolumn{2}{|c|}{$\begin{array}{c}\text { Model B: } \\
(1,2,1,1,2,2,2)\end{array}$} & \multicolumn{2}{|c|}{$\begin{array}{c}\text { Model C: } \\
(1,2,1,1,2,1,1)\end{array}$} \\
\hline & \multicolumn{2}{|c|}{$4.75 * * *$} & \multicolumn{2}{|c|}{$7.45^{* * *}$} & \multicolumn{2}{|c|}{$8.79 * * *$} \\
\hline Long-run: & Coefficient & $\frac{\text { Standard }}{\underline{\text { Error }}}$ & Coefficient & $\underline{\text { Standard Error }}$ & Coefficient & $\frac{\text { Standard }}{\underline{\text { Error }}}$ \\
\hline$L F D I$ & $0.0242 * * *$ & $\overline{0.0080}$ & $0.1478 * * *$ & 0.0115 & $0.1500 * * *$ & $\overline{0.0156}$ \\
\hline$L T T$ & $0.0625 * *$ & 0.0243 & $0.0874 * * *$ & 0.0094 & $0.0918 * * *$ & 0.0156 \\
\hline$L D C$ & $-0.1705 * * *$ & 0.0449 & $0.4166^{* * *}$ & 0.0491 & $0.4009 * * *$ & 0.0609 \\
\hline$\angle P O P$ & $2.3849 * * *$ & 0.0913 & $1.5717 * * *$ & 0.0696 & $1.5714 * * *$ & 0.0910 \\
\hline Constant & $-28.2548 * * *$ & 1.3819 & $-20.1286 * * *$ & 0.7573 & $-20.1188 * * *$ & 0.9455 \\
\hline Crisis Dummy 1997 & & & $-0.1158 * * *$ & 0.0166 & - & - \\
\hline Crisis Dummy 2008 & - & - & $0.1707 * * *$ & 0.0183 & - & - \\
\hline LFDI $*$ Crisis Dummy & & & & - & $-0.0052 * * *$ & 0.0011 \\
\hline 1997 & - & - & - & & & \\
\hline LFDI * Crisis Dummy & & & & - & $0.00845 * * *$ & 0.0012 \\
\hline 2008 & - & - & - & & & \\
\hline
\end{tabular}




\begin{tabular}{|c|c|c|c|c|c|c|}
\hline Short-run: & Coefficient & $\frac{\text { Standard }}{\text { Error }}$ & Coefficient & $\underline{\text { Standard Error }}$ & Coefficient & $\frac{\text { Standard }}{\text { Error }}$ \\
\hline LFDI & $0.0173 * * *$ & $\overline{0.0028}$ & $0.0559 * * *$ & 0.0048 & $0.0508 * * *$ & $\overline{0.0042}$ \\
\hline$L T T$ & -0.0775 & 0.0746 & $-0.2713 * * *$ & 0.0635 & $-0.1724 * * *$ & 0.0503 \\
\hline$L D C$ & 0.0187 & 0.0249 & $0.1094 * * *$ & 0.0221 & $0.0902 * * *$ & 0.0222 \\
\hline$\angle P O P$ & $-6.1741 * * *$ & 1.1648 & $-8.6239 * * *$ & 1.1973 & $-7.1334 * * * *$ & 0.9803 \\
\hline ECT & $-0.7399 * * *$ & 0.0997 & $-0.9366 * * *$ & 0.1021 & $-0.7988 * * *$ & 0.0814 \\
\hline
\end{tabular}

\section{Diagnostic test}

\begin{tabular}{|c|c|c|c|}
\hline $\begin{array}{l}\text { Normality test, Jarque } \\
\text { Bera }\end{array}$ & $0.1795[0.9142]$ & $1.4912[0.4744]$ & $1.2944[0.5235]$ \\
\hline $\begin{array}{l}\text { Serial correlation, } \\
\text { BG-LM test }\end{array}$ & $1.2370[0.3166]$ & $3.1163[0.0621]$ & $2.2224[0.1533]$ \\
\hline $\begin{array}{l}\text { Heteroscedasticity, } \\
\text { BPG test }\end{array}$ & $1.7213[0.1384]$ & $1.6265[0.1627]$ & $1.3991[0.2421]$ \\
\hline CUSUM test & Stable & Stable & Stable \\
\hline CUSUM $^{2}$ test & Stable & Stable & Stable \\
\hline
\end{tabular}
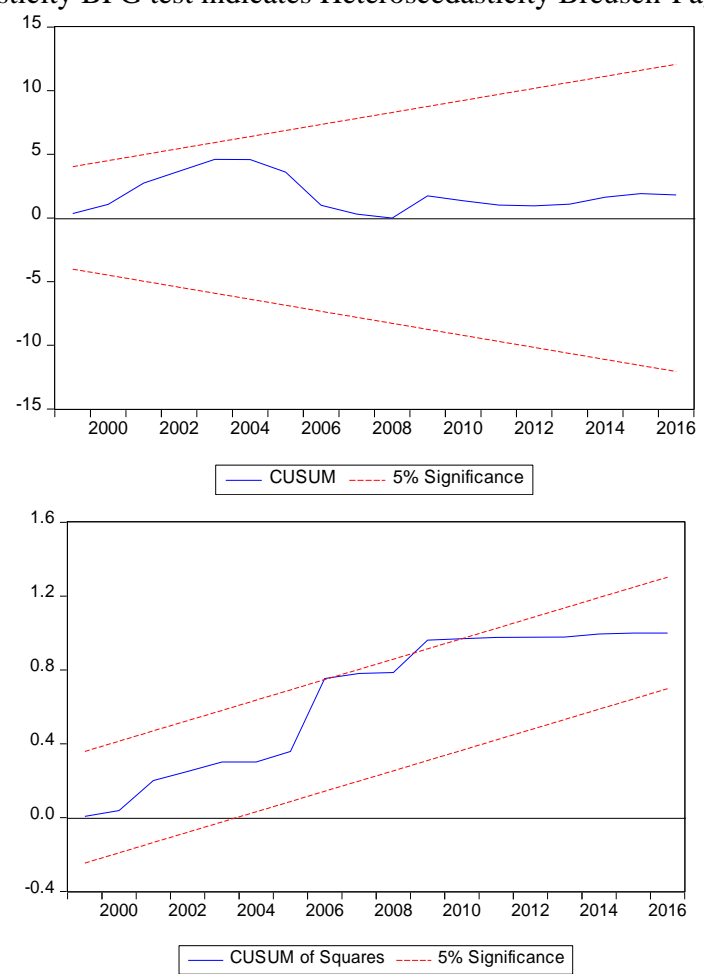

Figure 1. Stability Test for Model A

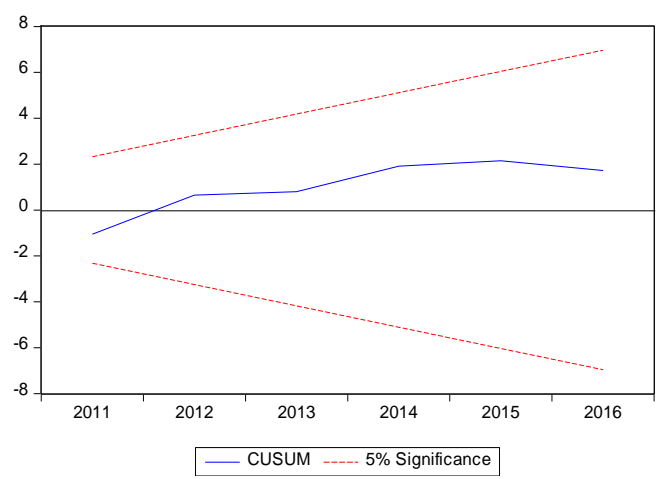




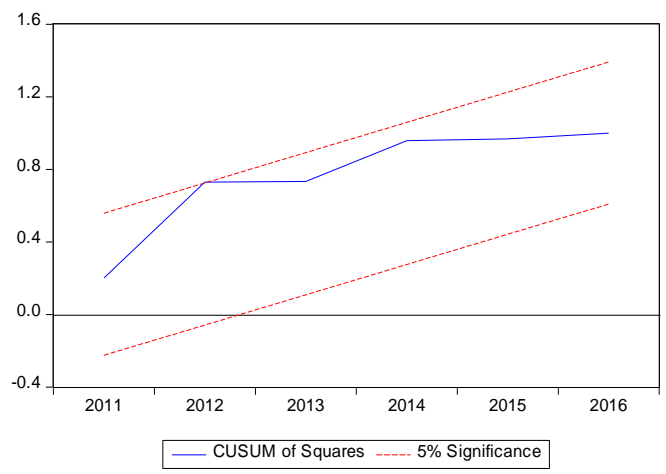

Figure 2. Stability Test for Model B
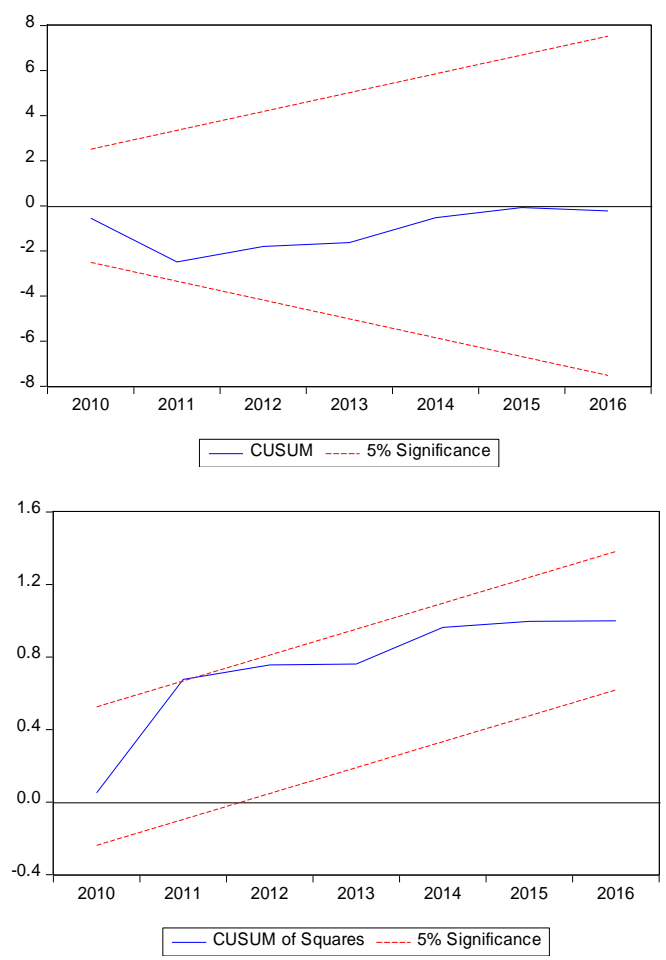

Figure 3. Stability Test for Model C

Table 3 show the results of Model A (GDP and FDI inflow with set of control variables), Model B (GDP and FDI inflow with set of control variables and crisis dummy 1997 and crisis dummy 2008) and Model C (GDP and FDI inflow with set of control variables and interaction between FDI inflow and crisis dummy 1997; interaction between FDI inflow and crisis dummy 2008). Based on the results of Model A, the $F$-statistic value of 4.75 is greater than the upper bound of 4.37 at $1 \%$ significance level and this signifies evidence of long-run equilibrium between the variables.

In terms of long-run perspective, there is a significant positive relationship between FDI inflow and GDP with coefficient of 0.02 and statistically significant at $1 \%$ significance level. Intuitively, $1 \%$ increase (decrease) in FDI inflow will lead to increase (decrease) of $0.02 \%$ in GDP of Malaysia. This result is congruent with Carbonell and Werner (2018), Mahmoodi and Mahmoodi (2016), Batten \& Xuan (2009), Duasa (2007), Chowdhury and Mavrotas (2005), Li and Liu (2005), Chakraborty and Basu (2002) and Liu, Burridge and Sinclair (2002).

The results of the other control variables also show significant relationship with GDP. Total trade and population have positive relationship with GDP with coefficients of 0.06 and 2.41, respectively. Domestic private credit has negative relationship with GDP with coefficient of 0.17. In the short-run, there is also positive relationship between FDI inflow and population have positive relationship with GDP with coefficient of about 0.02 and 5.67, respectively. Meanwhile, the relationship between total trade and domestic private credit with GDP are statistically insignificant. Moreover, the ECT result shows significant coefficient of about -0.74 , which signifies 
the speed of adjustment of about $74 \%$. In terms of the diagnostic test, the model passes all the diagnostic test of normality test, serial correlation test, heteroscedasticity test and stability test.

In order to capture the crisis effects, the results in Model B and Model C show that the crisis in 1997 and 2008 have impact on the relationship between FDI inflow and economic growth. The inclusion of the 1997 Asian Financial crisis in the estimation shows that there is significant positive relationship between FDI inflow and GDP of Malaysia in the long-run, with larger coefficient of about 0.21 . The results for total trade and domestic private credit are statistically significant, except for population. Interestingly, 1997 crisis dummy have negative impact on GDP while 2008 crisis dummy has positive impact on GDP. This may be due to the severe negative impact of 1997 Asian Financial crisis on ASEAN region and detrimental to economic growth. Meanwhile, the positive impact of the 2008 Global financial crisis may due to the severe impact that affected western region only.

The results in Model C provide more insight information regarding the interaction term between FDI with the crisis dummy. There is a positive relationship between FDI inflow and economic growth. The interaction term between FDI and 1997 crisis dummy indicates negative relationship with GDP with coefficient of about 0.02. This shows that the FDI inflow during the 1997 Asian Financial crisis may not contributed to the economic growth. This is due to the severe negative impact of the crisis that led to drastic drop of FDI inflow and capital flight during that period. Nevertheless, this phenomenon was transitory impact as FDI remain as prominent tool for economic growth in the long-run. The positive impact of the interaction term between FDI and 2008 crisis dummy may due to the impact only affected

\section{Conclusion}

This study intends to re-examine the role of FDI towards economic growth in Malaysia. Annually data from 1980 to 2016 are used in this study using Autoregressive Distributed Lag (ARDL) bounds test approach. This method enables to estimate the long-run and short-run relationship simultaneously. Empirical findings show that FDI inflow has positive relationship with economic growth of Malaysia. This means the FDI-led-growth hypothesis remain valid in this era. Furthermore, FDI has a negative association with economic growth during the 1997 Asian Financial crisis. This is due to the severe impact of the crisis that mainly affected most of the countries in the Southeast Asia region. However, there is a positive impact of FDI on economic growth during the 2008 Global Financial crisis. This may due to the consequences of the crisis that affected western region. Moreover, this provide opportunity for the East Asia countries in terms of FDI preference. In the nutshell, FDI still play essential role in stimulating the economic growth of Malaysia in the long-run. Although, FDI inflow may be affected during the crisis period, especially if the crisis hit on the East Asia region, however, it is undeniable that FDI remain valid to economic growth. Therefore, policy makers should continue to develop strategies to attract FDI inflow into the country to ensure sustainable economic growth via higher productivity level. One of the critical concerns is the availability of skill workers or expatriate, which is important in terms of technology transfer. This can be done by revising the bureaucratic procedure in engaging and employing relevant expertise in the manufacturing sector for example. Besides that, the stability of the economy is also essential to enhance the confidence level of the investors where the government may need to ensure prudent management of expenditure and debt level.

\section{References}

Batten, J. A., \& Xuan, V. V. (2009). An Analysis of the Relationship Between Foreign Direct Investment and Economic Growth, Applied Economics, 41, 1621-1641. https://doi.org/10.1080/00036840701493758

Blomstrom, M., \& Wolff, E. N. (1994). Multinational Corporations and Productivity Convergence in Mexico, in Convergence of Productivity: Cross-National Studies and Historical Evidence (Eds) W. Baumol, R. Nelson and E.N. Wolff, Oxford University Press, Oxford, 263-284.

Borensztein, E., De Gregorio, J., \& Lee, J. W. (1998). How Does Foreign Direct Investment Affect Economic Growth, Journal of International Economics, 45, 115-135. https://doi.org/10.1016/S0022-1996(97)00033-0

Carbonell, J. B., \& Werner, R. A. (2018). Does Foreign Direct Investment Generate Economic Growth? A New Empirical Approach Applied to Spain, Economic Geography, 94(4), 425-456. https://doi.org/10.1080/00130095.2017.1393312

Chakraborty, C., \& Basu, P. (2002). Foreign Direct Investment and Growth in India: A Cointegration Approach, Applied Economics, 34, 1061-1073. https://doi.org/10.1080/00036840110074079

Chowdhury, A., \& Mavrotas, G. (2005). FDI and Growth: A Causal Relations. WIDER Research Paper. Finland: UNUWorld Institute for Development Economics Research. 
Chuang, Y. C., \& Hsu, P. F. (2004). FDI, Trade and Spillover Efficiency: Evidence from China's Manufacturing Sector, Applied Economics, 36, 1103-115. https://doi.org/10.1080/0003684042000246812

Dollar, D., \& Kraay, A. (2004). Trade, growth and Poverty, The Economic Journal, 114, 22-49. https://doi.org/10.1111/j.0013-0133.2004.00186.x

Duasa, J. (2007). Malaysian Foreign Direct Investment and Growth: Does Stability Matter. Journal of Economic Cooperation, 28, 83-98.

Hermes, N., \& Lensink, R. (2003). Foreign Direct Investment, Financial Development and Economic Growth, Journal of Development Studies, 40, 142-63. https://doi.org/10.1080/00220380412331293707

Li, X., \& Liu, X. (2005). Foreign Direct Investment and Economic Growth: An Increasingly Endogenous Relationship, World Development, 33, 393-407. https://doi.org/10.1016/j.worlddev.2004.11.001

Liu, X., Burridge, P., \& Sinclair, P. J. N. (2002). Relationships between Economic Growth, Foreign Direct Investment and Trade: Evidence from China, Applied Economics, 34, 1433-1440. https://doi.org/10.1080/00036840110100835

Mahmoodi, M., \& Mahmoodi, E. (2016). Foreign Direct Investment, Exports and Economic Growth: Evidence from Two Panels of Developing Countries, Economic Research, 29(1), 938-949. https://doi.org/10.1080/1331677X.2016.1164922

Narayan, P. K., \& Narayan, S. (2005). Estimating Income and Price Elasticities of Imports for Fiji In a Cointegration Framework, Economic Modelling, 22, 423-438.

Pesaran, M. H., Shin, Y., \& Smith, R. J. (2001). Bounds Testing Approaches to the Analysis of Level Relationship, Journal of Applied Econometrics, 16(3), 289-326.

Schmitt, D., \& Alexiou, C. (2016). On the FDI-led Growth Hypothesis: Empirical Evidence from Ireland, The Empirical Economics Letters, 15(2), 136-144. https://doi.org/10.1080/1350485042000228268

Schneider, P. H. (2005). International Trade, Economic Growth and Intellectual Property Rights: A Panel Data Study of Developed and Developing Countries, Journal of Development Economics, 78, 529-47. https://doi:10.1016/j.jdeveco.2004.09.001

United Nations Conference on Trade and Development (UNTACD) Report.

Wang, C., \& Yu, L. (2007). Do Spillover Benefits Grow with Rising Foreign Direct Investment? An Empirical Examination of the Case of China, Applied Economics, 39, 397-405. https://doi.org/10.1080/00036840500428096

World Development Indicators, World Bank.

World Economic Outlook, International Monetary Fund.

Zhang, K. H. (2001). Does Foreign Direct Investment Promote Economic Growth? Evidence from East Asia and Latin America. Contemporary Economic Policy, 19, 175-185.

https://doi.org/10.1111/j.1465-7287.2001.tb00059.x

\section{Copyrights}

Copyright for this article is retained by the author(s), with first publication rights granted to the journal.

This is an open-access article distributed under the terms and conditions of the Creative Commons Attribution license (http://creativecommons.org/licenses/by/4.0/). 